\title{
Corporate social responsibility and stakeholder engagement in Ghana's mining sector: a case study of Newmont Ahafo mines
}

\author{
Peter Ansu-Mensah ${ }^{1 *}$ D, Emmanuel Opoku Marfo², Lyon Salia Awuah ${ }^{3}$ and Kwame Oduro Amoako ${ }^{4}$
}

\begin{abstract}
Even though the concept of Corporate Social Responsibility (CSR) has been applauded for several decades, the concept of stakeholder engagement is relatively new to the Ghanaian mining sector. This study investigates the CSR process of an extractive company and examines how stakeholders are engaged in CSR. Using purposive and snowball sampling in identifying its respondents, data was gathered through interviewing 21 selected respondents from various stakeholder groups and documents such as sustainability annual reports were analyzed. It was discovered that Newmont Ahafo Mines has consistently had a prominent CSR drive in Ghana for several years and stakeholder involvement in CSR is important for implementing relevant CSR programs. Findings of this study contribute to the building of empirical reference which will serve as guidelines for management practitioners dealing with stakeholder relations and CSR in Ghana's mining sector. Therefore, it is recommended that the mining sector put immense effort in engaging various stakeholders in their CSR initiatives.
\end{abstract}

Keywords: Corporate social responsibility, Stakeholder engagement, Gold mining sector, Newmont Ahafo mines, Ghana

\section{Introduction}

Pressure emanating from stakeholder groups such as nations and civil societies has directed several companies to change their policies towards achieving corporate citizenship. Equally, the global economic crises that have been witnessed in the twenty-first century have resulted in a phenomenal change in the private sector's relationship with governments. Consequently, several organizations are looking to rebuild the shattered trust of a significant number of stakeholders (Bice, Brueckner, \& Pforr, 2017; Pirson, Martin, \& Parmar, 2017). And in addition to profit making objectives, businesses have allocated resources for social investments in societies

\footnotetext{
* Correspondence: peter.ansumensah@ymail.com; p.ansumensah@stu.edu.gh 'Department of Marketing, Faculty of Business and Management Studies,

Sunyani Technical University, Sunyani, Bono Region, Ghana

Full list of author information is available at the end of the article
}

(Foss \& Klein, 2018). It is no wonder that corporate social responsibility (CSR) and stakeholder engagement are continuously picking up significance in the globalized business world (Hasan, Kobeissi, Liu, \& Wang, 2018). In line with this, many businesses have altered their policies and operations and integrated the idea of CSR as a way of protecting their hard earned reputation (Hasan et al., 2018).

CSR simply refers to the obligations that companies have to society. It is the obligations to stakeholders and those who are influenced and affected by corporate policies and practices (Kowalczyk \& Kucharska, 2020; Morsing \& Schultz, 2006). Since communities have relief expectations from businesses, certainly corporate bodies have the mandate to fulfill these expectations. Lewa (2020), has suggested that society tends to reward organisations that are considered to be socially responsible 
in different ways. Thus, in order to enhance corporate image, companies have been progressively urged to embrace policies beyond the economic elements of their company and to consider CSR in their company activities (Park, Chidlow, \& Choi, 2014). Therefore, organizations are creating a highly regarded CSR issues so that they can achieve stakeholder trust (Nichols \& Dowden, 2019). While opinions differ on how engagement should be allocated across the public and private sectors, corporate stakeholders are demanding that companies recognize a broader scope of responsibility in addressing those problems which in turn hinders their reputation (Nave \& Ferreira, 2019). As a result, firms are increasingly collaborating with stakeholders to come to terms with their views and concerns regarding different environmental, social, corporate governance and economic concerns which are often alluded to as issues of CSR and to incorporate and address those views and concerns in the company's strategic decision-making processes (Agudelo, Jóhannsdóttir, \& Davídsdóttir, 2019; Iglesias, Markovic, Bagherzadeh, \& Singh, 2020).

In the area of Mining Corporation there is available information on CSR and Stakeholder Management. It has been noted that the two hypotheses intersect (Korppi, Mecklin, \& Heikkilä, 2019). Nonetheless, a crucial literature search shows that the examination of CSR and Stakeholder Management work has primarily concerned with their connection with business performance (Yang \& Stohl, 2020). By demonstrating responsiveness and accountability to stakeholders with regard to CSR issues, one would hope that the corporate reputation would flourish and the organization's market performance would benefit. "Good stakeholder engagement and accountability should focus on addressing these social, environmental, economic and ethical expectations" (O'Dwyer \& Unerman, 2016; Unerman \& Zappettini, 2014). However, it is only through consultation and engagement that it is possible for managers to develop an understanding of their stakeholders' expectations. For social responsibilities to be taken seriously, mechanisms need to be employed which allow stakeholders' views to feed into the organizations' decision-making process and which will ensure that organizations are held accountable to stakeholders' expectations. According to Luu (2019), co-creation activities will help stakeholders feel good about the organisation and they will be less susceptible to negative information and develop feelings of loyalty. This notwithstanding, studies such as Korppi et al. (2019) claims that corporations have limited engagements with their stakeholders particularly in times of crisis which ultimately affect their reputation. This study, therefore, seeks to address this challenge by studying how stakeholder engagement can influence corporate reputation.
Again, insufficient research has examined the connections between stakeholder management and CSR (Carroll \& Brown, 2018; Harjoto \& Laksmana, 2018). Carroll and Brown (2018), clarifies that there is a characteristic fit among CSR and stakeholder management, however, stakeholder technique is not feasible and requires compromising of smart business goals. This reasoning may have been the cause of less examinations looking at the relationship. Additionally, Halme, Rintamäki, Knudsen, Lankoski, and Kuisma (2020) opined that in spite of the recognized significance of stakeholder management, CSR study still needs both theoretical understanding and practical proof of different stakeholder related issues. Kapoor et al. (2018), acknowledged that current limited studies mainly centered on the conceptual advancement of stakeholder management tools and systems.

Developing economies, including Ghana, are trying to follow the path of developed nations and in this direction embrace developed countries' values and guidelines on CSR practices. Majority of the studies on stakeholder engagement covers the developed economies and a little bit work was found in emerging and developing countries including Ghana's economy (Patnaik, Temouri, Tuffour, Tarba, \& Singh, 2018). Ghana has an estimated population of 30.42 million, out of which about 12.84 million constitute the labour force (Ghana - Total Labor force, TLF, 2019; World Population Review, 2019). As a developing nation, there are many domestic and foreign companies working in the country. These companies normally focus on earning and maximizing wealth without considering their negative/adverse social and environmental effect on stakeholders, even though such activities are not permitted in developed countries (Martínez-Ferrero, Garcia-Sanchez, \& Cuadrado-Ballesteros, 2015). Moreover, an investigation by Ofori and Debrah (2014) attempts to explain that corporate stakeholders like clients, government workers and Non-Governmental Organizations (NGOs) are significant drivers of stakeholder engagement initiations and activities. Despite that how such stakeholder engagement can really promote corporate image have not been very much investigated, particularly in environmental sensitive industries such as the mining sector in developing countries.

The aim of this study is to examine CSR practices and stakeholder engagement in CSR practices in the Ghanaian mining sector using Newmont Ahafo mines as the case study. The specific objectives are as follows: to explore the CSR practices undertaken by Newmont Ahafo Ltd., and to evaluate the mode of stakeholder engagement in CSR practices of Newmont Ahafo Ltd.

This paper contributes to the discussion on CSR and stakeholder management among mining companies as follows: In theory, extra information on the correlation between CSR and stakeholders behaviour is needed. This 
will allow companies to use this study to apply CSR strategies to assist them attain greater stakeholder engagement and, therefore, increase the overall performance of their companies. Due to this, companies can also identify stakeholder expectations. In practice, over the past decade, stakeholders have increasingly expected businesses to be socially accountable, and this is part of the reason and how stakeholders create engagement. CSR activities can also assist the mining sector to achieve competitive advantages that peer mining sector may not enjoy. In this situation, CSR actions also help the mining sector in Ghana not only to attract and maintain their clients, but also, to assist them to attract and retain talented and motivated employees. This study will likewise fill in as a guide as to how the commercial mining sector can change stakeholders' perceptions of their products and services through the use of CSR actions to generate patronage.

\section{Literature review/theoretical underpinning Review on the concept of CSR}

Martínez-Ferrero, Rodríguez-Ariza, and García-Sánchez (2016), characterized the direction of CSR as the duty of policy-makers to take steps that will not only satisfy their own desires and needs but also secure and help improve public economic power (Idowu, Capaldi, Fifka, Zu, \& Schmidpeter, 2015; Morsing \& Schultz, 2006). Similarly, Gold, Muthuri, and Reiner (2018), see CSR as acts which lead to sustainable development along the key business operations of the organization, social good and the discourse on government policy.

From the interpretations above, it can be noted that a company adds to the welfare of both the immediate and distant owners by way of its CSR practices. It can, therefore, be described as the obligation of an organization to conserve any environmental or human resource that adds to the standard of living of stakeholders for whom the well-being is regarded an important indicator of sustainability. Actually, business's CSR practices are not primarily results-driven, but are also taken into consideration the impending needs of the society as well as other interested parties. Consequently, the aforesaid definitions have been chosen as basis for the present study.

\section{The global context of the role of CSR}

White and Alkandari (2019), postulated that CSR strategies cannot be separated from contextual considerations which includes cultural, political, and economic elements due to the fact that countrywide environments shape CSR practice. Thus, a project of CSR research in the worldwide environment is not simply to describe CSR exercise in one of a kind international location, however, also to discover how the infrastructure of a country (political and monetary elements) and societal expectancies (way of life) can also have an effect on it. Previous research has indicated that the subculture of a country affects CSR exercise (Adnan, Hay, \& van Staden, 2018; Kucharska \& Kowalczyk, 2019).

In the United States, CSR is mainly influenced by the private sector's involvement, as well as collaborations between public corporations and the American government. White and Fitzpatrick (2018) claims that Communication Executives in the USA perceived no responsibility for their employer to promote the image of the USA, rather they argue that the USA government is being too careful in taking risk. Nonetheless, with or without authority's involvement, organizational positive image could emanate from CSR. It is further argued that good positive image of firms positively impact on the USA which is the country of the corporations' origin (Brooks \& Oikonomou, 2018).

In many countries, governments are focusing more on CSR practice and value the relationship among CSR and the country's image. The government of Canada, for instance, inspires multinational Canadian agencies to be ethically responsible since CSR have an effect on the image of the entity as well as that of Canada (Brooks \& Oikonomou, 2018). The Canada government offers CSR guidelines for Canadian corporations and diplomatic missions globally as a means of boosting them to collaborate and improve upon the relationship between Canada and different countries through CSR initiatives (Lamb, Jennings, Calain, \& Society, 2017). Analogous to the Canadian government, the Swedish government performs key functions in CSR initiatives in Sweden and actively helps CSR campaigns that improves upon the Swedish corporations image (Corvellec \& Stål, 2019).

In China, Yang, Ma, and Doty (2020), discussed two forms of CSR: the first one is on family-owned SMEs (small and medium-sized enterprise) with emphasis on local reputation. The second form of CSR is in the corporate, which are mostly governmental organizations, demonstrating global and national societal expectations. Furthermore, Lee and Chan (2017) argues that CSR in China has been driven by government initiatives and the introduction of mandatory environmental and social responsibility reporting. The authors claim that CSR is mostly common among large-scale corporations. In Hong Kong, CSR is both large corporations and SMEs are self-motivated to carry out CSR practices which is most likely to be motivated by way of agency tasks assuming a bottom-up approach among various stakeholder groups (Lee \& Chan, 2017).

Corporate philanthropy in the Middle Eastern countries is key in CSR practices and it is driven by core Islamic cultural values (Ronnegard, 2009). The support of philanthropic CSR in the Middle East is mainly due to Islamic values such as zakat (i.e. obligatory giving as one of the five pillars of Islam). Again, Goby and Nickerson (2016) 
argues that religious values have impact on stakeholders' expectations on CSR in Dubai, since the expectation for philanthropy is key to Islamic culture.

\section{Legitimacy, stakeholder, and institutional theories}

Stakeholder theory and Legitimacy theory are the most often used theoretical perspectives in CSR research (Coffie, Aboagye-Otchere, \& Musah, 2018). These two theories are gotten from the common type of Political Economy Theory (PET) to clarify practices of CSR (Bice et al., 2017; Looser \& Mohr, 2020). Legitimacy theory suggests social contract between the business entities and society and the organizations' sustenance is subjected to the presence of endorsement given by society. Organisations attempt to win this endorsement from the individual citizenry in the host communities by taking part in CSR practices (Brueckner \& Eabrasu, 2018; Zhang, Oo, \& Lim, 2019). The stakeholders are the individuals in the host communities; in this way, Stakeholder theory manages the relationship that has transpired between the corporations and the stakeholders. Institutional theory then has a cozy relationship with stakeholder as a web of stakeholders and their relationship and relative qualities may be considered as fields (Franklin, 2020; Prno \& Slocombe, 2014). Institutional and stakeholder theories among other things study the relationships that exist between corporations, host communities, and the general environment. Both of these theories add to one another in the comprehension of how organisations identify with their appropriation of CSR practices.

In spite of the fact that there is an extensive relationship between these three theories, most CSR research have utilized a single theory point of view in a particular time. This methodology confines the logical intensity of empirical indications, since theory is consistently inadequate in the social sciences (Ablo, 2020; Brueckner \& Eabrasu, 2018). Hence, this study reacts to this gap by developing a theoretical structure that coordinates these three theories together to dissect and clarify empirical evidence of CSR practices in Ghana. The philosophy of these standard CSR theories, their utilization in the CSR writing, and the development of this structure are talked about in this research. Institutional theory is a settled theoretical point of view in the areas of managerial decision, political sciences, social and organisational behaviour, bookkeeping controls, and financial reporting, however comparative to stakeholder theory and legitimacy theory, it has not been utilized much in the CSR writing (Ablo, 2020). Nevertheless, as put forward by Laosirihongthong, Samaranayake, Nagalingam, and Adebanjo (2020), institutional theory has the ability to help clarify CSR compliance by organisations. The new institutional theory accentuates the vital part of social and traditional ramifications and pressures that forced corporations to influence their CSR behaviours and practices. While accepting that different theories are utilized by CSR studies, it accentuates that stakeholder, legitimacy, and institutional theories give more understanding theoretical perspective on CSR practices than different theories offer, particularly while thinking about simply financial theories (Chedrawi, Osta, \& Osta, 2020).

\section{Stakeholders of an organisation}

Freeman describes a stakeholder as any person or party who can influence or is influenced by the success of the company's objectives (Freeman \& Dmytriyev, 2017). In a subsequent release Freeman described stakeholders as all groups that are crucial to the company's existence and growth as cited in (Kujala \& Korhonen, 2017). The key stakeholder categories are owners, clients, staff, indigenous communities, suppliers and distributors. Other stakeholder categories involve scholars, non-governmental organizations (NGOs), the state and the broadcasting companies (Freeman \& Dmytriyev, 2017). Stakeholders underlying strategy to CSR means that their contribution can be integrated into the designing of meaningful CSR programs and assist restructure and strengthen activities. Stakeholders may be identified as primary (those whose continued involvement is crucial to the success of the company) or secondary - those not critical for the sustainability of companies (Ranängen, 2017).

\section{Stakeholder engagement}

Stakeholder engagement can be regarded as those strategies that an organization conducts to positively include interested parties in organizational operations (Amoako, 2017). This will cover the process of creating, improving and maintaining ties with stakeholders. This may include interested parties' recognition, consultation, collaboration, discourse and interaction (Andrews, Andrews, \& Yurova, 2019). Quite recently, the ISO 26000 standards of social responsibility identify stakeholder engagement as all actions initiated to establish conditions for interaction between an organization and one or more of its interested parties in order to provide an effective ground for the organization's decisions (Del Baldo \& Aureli, 2019).

In summary, the reason behind the usage of the word 'engagement' in the literary works on stakeholder concept and CSR is the need to stress that it is no longer enough for businesses to simply communicate with stakeholders. Rapport with stakeholders is practically appropriate business operation (Aggarwal \& Singh, 2019). In this sense, engagement may be regarded as a system for achieving a range of strategies, such as agreement, power, collaboration, transparency and participation, as a tool for reinforcing trust or as a replacement for real 
confidence, as a discussion for boosting justice or as a system for corporate governance (Boadi, He, Darko, \& Abrokwah, 2018; Mensah, Agyapong, \& Oteng-Abayie, 2017).

Ideally, participation of stakeholders should be viewed as a commonly beneficial and a collaborative arrangement taking the form of a 'moral partnership of equals' (Adongo, Kim, \& Elliot, 2019). In this context, a number of economic and behavioural perspectives offer different extra insights for observing the autonomy in these partnerships (Rendtorff et al., 2018). Furthermore, Ansong (2017) contends in examination of the different potential interpretations of stakeholder engagement from different theoretical frameworks like corporate ethics, social accounting and reporting as well as personnel management that stakeholder engagement is often morally neutral. As a result, it can either be done legitimately or immorally. In business culture it is the value of the actor that eventually establishes the purpose behind the pursued engagement. Consequently, engagement with stakeholders does not automatically match with responsible business behaviour (Mohammed, Xiao, \& Hilton, 2019). Therefore, the contention that stakeholders' engagement is related to businesses being accountable to stakeholder is over simplified.

A key objective of corporate stakeholder engagement is to establish relationships with stakeholders to properly appreciate their opinions and concerns on relevant issues and to factor those perspectives and concerns (when and where feasible and prudent) into the company's corporate strategy (Hermelline \& Beddewela, 2019; Panda \& Barik, 2014). Stakeholder engagement pertains to the formal and informal means a firm stays associated to its stakeholders (Lenssen \& Yuthas, 1997; Shnayder, van Rijnsoever, \& Hekkert, 2016). Indeed, evidence in literature clearly indicates that stakeholder engagement has a crucial role to play in CSR (Park et al., 2014).

\section{CSR and stakeholder engagement}

Asante Boadi, He, Bosompem, Say, and Boadi (2019), explored the methodology, degree, justification and ramifications of stakeholder involvement in CSR management. The results indicate that totally discretionary CSR and participation of stakeholders will reduce its strategic effects and sustainability. To prevent this, there is a need for some mechanism to increase the informed engagement of appropriate stakeholders and promote viable CSR practice.

Osei-Kojo and Andrews (2020), discovered that the commitment seems too managed and lacks genuineness; and that process of stakeholder engagement required to enhance informed and balanced involvement of stakeholders and continuous development of CSR initiatives.
Conversely, Abugre and Anlesinya (2020) analyzed CSR and the small company stakeholders employing a quantitative research methodology. This research showed that the local people are very significant stakeholders of small companies and that their contribution to the community is usually relatively comprehensive. A further research done by (Khan, Muttakin, \& Siddiqui, 2013) found that there are no statistically relevant variations in levels of involvement between staff subjected to external and internal CSR strategies.

\section{Gold mining business in Ghana}

Ghana, which is ranked second only behind South Africa as the leading producer of gold in Africa, is recognized as the chief exporter of timber and other minerals such as bauxite and diamond (Mehahad \& Bounar, 2020). The recent minerals law passed by the parliament of Ghana in 2006, Act 703 which was amended in 2015 add up to the various reforms in the mineral laws and policies in the country and this has led to the quick expansion in the mining business of Ghana (Hilson, Hilson, \& Dauda, 2019). This growth has seen a greater increase in the country's foreign direct investment, contributed to the foreign exchange earnings, and employing about 24,000 people, Ghana Chamber of mines (Boso, Afrane, \& Inkoom, 2017).

Much the same as in numerous industries, the stakeholders in the gold mining business are extremely relevant. According to Shiu and Yang (2017), stakeholders' expectations of businesses have increased so drastically that, given the magnitude of these demands, big and small businesses find it progressively hard to evade their corporate social obligation. Martinez-Conesa, Soto-Acosta, and Palacios-Manzano (2017) concur with Erdiaw-Kwasie, Alam, and Shahiduzzaman (2017) and clarified that the sustainability and performance or achievement of a company relies upon the capacity of its managers to create adequate income and fulfillment for its major stakeholders. The activities of the company are negatively impacted when stakeholders pull back their funding from the company (Lenz, Wetzel, \& Hammerschmidt, 2017). The adverse impacts of mining on indigenous populations have been very much reported (Boso et al. (2017) and these have made stakeholders mindful of the degree of negative effects on their lives and subsequently have expanded their interest for responsibility. The main contention has generally focus on the unavoidable by-product of economic, social and environmental cost of mining, indigenous population's loss of resources, and the unequal allocation of their costs and benefits. Hilson et al. (2019) have observed that the adverse impact of mining is focused unfairly on the less endowed segments of the society. This study, therefore, seeks to investigate into CSR and stakeholder engagement practices in the Ghanaian mining sector using Newmont Ahafo Ltd. as a case study. 


\section{Nature and form of CSR in the mining sector}

Abugre (2014), who investigated the role of CSR in growth of the minerals business in South America, indicated that the CSR of the mining sector takes on the form of healthcare, school, clean drinking water and living standards. The results of the research again indicated that CSR interventions seem to have had a significant total effect on the neighborhood surrounding the mines, as there has been a considerable advancement in the standard of healthcare provided in the communities and $85 \%$ of the areas surrounding mining companies have access to drinking water, contributing to advancement in the overall standard of living of the people. In a whole, Organizations in Ghana typically engage in various kinds of CSR practices such as education and event promotion, and there is no concrete policy structure specifying the boundaries of CSR practices in Ghana. Nevertheless, directors of companies often have a CSR mentality that gets beyond corporate humanitarian efforts to strategic efforts that react to the varied concerns of the communities in which companies are run (Ofori \& Debrah, 2014).

Examining the essence of CSR pursuits from a marketing point of view, Sajjad and Eweje (2014), scrutinized social responsibility programs by both Turkish and international companies. The requirements employed to pick the companies were centered on companies whose social responsibility programs were considered as education, healthcare, climate, tradition/art, sport, history and community programs. In a similar research, Abukari and Abdul-Hamid (2018) demonstrated that education-lined activities made up predominant kind of CSR commitment in Malaysia. Their research also showed that the most significant category was legal responsibility while the least significant category was ethical responsibility.

\section{CSR in Ghana}

The CSR sector has developed significantly over the last years and lots of organizations have become more involved in helping society recently than before and CSR concerns have now been incorporated into all facets of company's activities (Ofori \& Debrah, 2014). In the same direction as (Marfo et al., 2017; Ofori \& Debrah, 2014), also stated that the idea of CSR is that businesses incorporate social and environmental issues into their business activities and actively engage with interested parties. In this current day, there is appeal on business entities to pursue social activities, as state alone cannot manage societal issues and this has influenced the adoption of the definition of CSR in the country (Amoako, 2017). Ghana faces economic difficulties including low per capita income, devalued currency, stagnant growth, low deposits, making it extremely difficult for local businesses to take social practices (Amponsah-Tawiah \&
Dartey-Baah, 2016). Abugre and Anlesinya (2019), opined that in Ghana, the position of management in CSR activity is restricted and inadequate. They found that the challenges of successful CSR execution stem mainly from lack of leadership engagement, leadership flaws in the area of incompetence and corruption, and reluctance to distribute money attributed to CSR initiatives. Again, Abugre and Anlesinya (2020) confirmed that businesses will perform well in CSR activity if management has a constructive approach to CSR and job performance. In his investigation on officials and the executives perspectives on CSR and morals in Ghana, Amoako (2017) revealed that corporations are interested in various CSR activities such as education funding, event patronage, and charity donations, although there is no legal structure for CSR in Ghana. Thus, corporate executives think that the social responsibility and ethical conduct is relevant for their businesses. A report in 2009 indicates that the engagement of the state in CSR in Ghana relies on the legitimate aspect which obliges companies to comply with the law (Damoah, Peprah, \& Cobla, 2019). There is no full package of CSR policies or regulations in Ghana, however there are a range of regulations, rules, procedures and programs that direct CSR programs in Ghana and the government seeks to encourage CSR by adopting regulation that establishes basic standards of business efficiency, like statutes, local authority regulations and environmental impact evaluation criteria found in a parliamentary statute. The results of an investigation by Sarpong (2017) on the point of view of CSR by major businesses in Ghana suggested that while indigenous firms are familiar with the definition of CSR and actually practice a certain extent of CSR, they commit less to the conventional definition of CSR; they are less tactical and less ethical in their response to CSR. Therefore, globally oriented Ghanaian businesses seem to have a greater understanding of the different aspects of CSR and the way these could be adopted for commercial and competitive benefit.

\section{Method}

This study was undertaken within the boundaries of gold mining operations in Ghana. Since gold is by far the most lucrative mineral operation in Ghana and therefore considering different minerals in the mining industry could be problematic. This is because conflicting indicators could have manifested in exploring different kinds and methods of mineral extraction. So, this option was necessary to preserve the paper's credibility. Certain extraction operations such as bauxite and crude oil were not included, even though they have similar requirements of gold mining organization's corporate social responsibility. 


\section{Research design}

This research used a qualitative case study approach and an exploratory research design since it tries to understand a subject of study in a preliminary way. This was more appropriate as the study seeks to delve deep into the role of stakeholder engagement in CSR practices of Newmont Ahafo Mines (Saunders, 2012; Creswell, 2014).

Newmont Ahafo Mines (NAM) is a subsidiary of Newmont Ghana Gold Limited (NGGL) with its parent company Newmont Mining Corporation (NMC) which is based in Denver, USA. NMC is a gold producer with properties in Ghana, Australia, Peru, Indonesia, Canada, New Zealand, and Mexico (Boso et al., 2017; FernándezLlamazares et al., 2020). NGGL is located in two administrative regions of Ghana (Ahafo mines in Asutifi North District Assembly of Ahafo and Akyem operations in Eastern Region of Ghana). Whilst the NGGL's actual operations began in the Ahafo area in 2006, the Akyem processes in Eastern region started in 2013 (Boso et al., 2017). The NAM is situated in the Asutifi North District Assembly of Ghana. It is notable that NAM is now the second main producer of gold in Ghana and has about 4400 workers and contractors (Boso et al., 2017).

\section{Sample and sample size}

In qualitative studies, it is argued that since the motive is not to generalize, a greater sample size does not matter (Saunders, 2012). In all, 21 participants representing a range of interest groups of different stakeholder categories including management, employees, chiefs, assemblymen, community representatives, governmental agencies, and non-governmental institutions. The sample of twenty-one was used for the study as the researchers reached data saturation. Data saturation is usually defined as the point when "no new information or themes are observed in the data" (Campopiano \& De Massis, 2015). Demographic characteristics of the respondents included gender, age and educational qualifications. There were seven NAM respondents, three managers and four staff members. Among these respondents', three were between 30 and 39 years whereas four were between 40 and 49 years and their respective education levels were bachelor degrees and postgraduate qualifications. There were also two females, and five males. Moreover, the two regulators were from the Environmental Protection Agency (EPA) and aged between 40 and 49 years and had postgraduate qualifications. Three traditional leaders represented the communities and were 40-60+ years. Besides, six representatives of the Sustainable Development Committee (SDC) members were aged between 30 and 39 years and $40-49$ years. Furthermore, two participants from the Organization for Livelihood Enhancement Services (OLIVES) were aged from 30 to 39, while one Newmont Ahafo Development Foundation
(NADeF) respondent was 36 years old. Lastly, for gender characteristics, fourteen (74\%) were males, whereas, seven (26\%) were females. As regards respondents' level of education, $69 \%$ of respondents had diploma, degree or postgraduate qualifications, $14 \%$ had JHS and SHS qualifications whiles $17 \%$ had no formal education. Table 1 illustrates the above discussed demographics.

\section{Sampling technique}

This study is an exploratory one that used purposive sampling and snowball sampling in identifying its respondents. Purpose sampling refers to the process of choosing particular individuals to take part in a study based on the knowledge of the respondent about the subject matter under investigation (Deng, 2012). The Community Affairs and the Environmental Manager were chosen because they play key roles in sustainability. They also led us to other key managers and employees. This approach is very popular in qualitative studies and much so in exploratory studies because it can provide a great in-depth analyzes into the phenomenon. Since not all stakeholders of Newmont Ahafo Ltd. are involved directly in the CSR initiatives, the option of these sampling techniques was more significant and useful in identifying relevant persons and authorities who were primarily involved in the CSR programs of Newmont.

\section{Data collection}

This section presents the type of data, their sources and the instruments used in gathering the data. The collection of primary data was done through the use of semistructured questionnaire interview guides, observations and secondary data. The number of participants interviewed were $\mathbf{2 1}$ and their affiliation, position, demographics, and interview length are included in Table 1. This study sought to examine how CSR is used as a tool to engage stakeholders of Newmont Ahafo Ltd. In that regard, the sources of data were both primary and secondary. The primary source of data was mainly interviews and observations used for data gathering from respondents. The secondary source of data was mainly annual reports and other published information which were found on the Website of Newmont Mining Corporation (Newmont, 2019a Annual Report).

Primary source of data is regarded as reliable because it originates directly from the population sample of the research. In this study, the researchers applied semi structured interview guide. The interview was carried out through the collection of data from stakeholders of Newmont Ahafo Ltd. The researchers used English for the interview with Newmont Management and employees but in the communities, the language used for the interview was the local dialect Akan (Twi). Data collection in the communities was relatively easy as most of 
Table 1 Demographics, stakeholder affiliations, position, and interview length

\begin{tabular}{|c|c|c|c|c|c|c|}
\hline Variable & Frequency & Percentage & Affiliations & Interviewee code & $\begin{array}{l}\text { Number of } \\
\text { participants }\end{array}$ & $\begin{array}{l}\text { Interview } \\
\text { length }\end{array}$ \\
\hline Gender & & & Newmont Ahafo & Management & 3 & $30-80 \mathrm{~min}$ \\
\hline Male & 7 & 33 & Newmont Ahafo & Employees & 4 & $30-45 \min$ \\
\hline Female & 14 & 57 & $\begin{array}{l}\text { Community Residents \& } \\
\text { Representatives }\end{array}$ & $\begin{array}{l}\text { Community } \\
\text { Members }\end{array}$ & 6 & $30-60 \mathrm{~min}$ \\
\hline Age & & & $\begin{array}{l}\text { Environmental } \\
\text { Protection Agency }\end{array}$ & Regulators & 2 & $35-85 \mathrm{~min}$ \\
\hline $20-29$ & 5 & 24 & Chiefs & Traditional rulers & 3 & 28-35 min \\
\hline $30-39$ & 1 & 5 & $\begin{array}{l}\text { Newmont Ahafo } \\
\text { Development } \\
\text { Foundation }\end{array}$ & NADeF & 1 & 34-41 min \\
\hline $40-49$ & 4 & 19 & NGOs & Environmentalists & 2 & $42 \mathrm{~min}$ \\
\hline $50-59$ & 9 & 43 & & & & \\
\hline $60+$ & 2 & 9 & & & & \\
\hline \multicolumn{7}{|l|}{ Education } \\
\hline No Formal Education & 17 & 17 & & & & \\
\hline$J H S \& S H S$ & 14 & 14 & & & & \\
\hline Diploma, Degree \& Postgraduate & 69 & 69 & & & & \\
\hline
\end{tabular}

the community representatives and chiefs were willing to assist. Every interview was documented and transcribed with the permission from the research participants. Few observations were also made to buff up the data. These observations were recorded in a pocket note book that the researchers carried along.

All interviews were recorded and before recording any interview, participants consent were sought. In addition, confidentiality and anonymity were ensured by the researchers. Moreover, because this study was solely for academic purposes, the respondents were not identified by their names but rather, with codes during the dissemination of results. The confidentiality and privacy of the respondents was assured, hence information or data provided by the respondents will be kept confidential. More so, the respondents' involvement and participation in the study was based on voluntary term and not coerced or induced with any form of monetary reward.

\section{Data analysis}

By the use of qualitative and descriptive methods, the data collected were thematically examined. Information collected from all aspects of the interview and discussion was transcribed from audio to readable format. The data was evaluated according to topics and content, as this offered a better understanding of the issues being discussed. Data was then coded, decreased to size, the topics from the text segments were outlined, constructed the networks, similar and consistent groups were arranged and categorized, the thematic network was analyzed, the network was summarized and patterns were constructed sequentially (Brunson \& Laubenbacher,
2018). Thematic analysis goes further than counting explicit words or phrases, and concentrates on the identification and description of ideas both implicit and explicit (Karlöf et al., 2019; Sodhi \& Tang, 2018). Additionally, exact quotes from the respondents were incorporated into the discussion. This was intended to give the research a voice, as it expresses their intentions, emotions and opinions.

\section{Validity and reliability}

In conducting qualitative studies, Karlöf et al. (2019) argues that "there is no right or wrong answer, but some methods will be better choices than others for particular research topics" (p. 103). In this study, we used competing perspectives from various stakeholders of Newmont Ahafo Ltd. in order to enhance validity and reliability (Adusei, 2017). To answer the research questions, three data collection procedures were used for this study: semi-structured interviews, observations and secondary data. Data reliability is the degree to which data gathering techniques produce reliable results.

\section{Results and discussion}

\section{Nature and form of CSR projects}

The study's first objective was to identify the nature and form of CSR initiatives conducted by Newmont Ahafo Limited (NAL) within the six sampled communities. To achieve this objective, questions were posed to management and personnel responsible for CSR operations and development projects at NAL. Related concerns were also presented to the different stakeholders as they were the end users of CSR ventures. 
Reactions from the participants indicated that NAL conducts CSR programs apart from its daily operations as a mining firm. Based on the interactions with the respondents from NAL and the community, the researchers formulated different wider themes where NAL's CSR initiatives and services typically fell under, thereby providing a foundation for the groupings. The key concepts for the nature of CSR programs that NAL participates encompass: health, education, water and sanitation, and quality of life. The quality of life fields of CSR includes; security and safety, development of human capital, poverty alleviation programs, rural development, environment, and agriculture types of CSR.

\section{Health}

It was noted in the course of the data collection period that a number of health facilities had been built by NAL for their host communities, Kenyasi No. 2 and Yamfo. With regard to health related CSR, respondents concluded that the company had put up male and female blocks, and maternity block for Ntotroso Government hospital and a clinic at Kenyasi No. 1 respectively. NAL has also established a modern operating theatre, and a placenta treatment plant for the hospital. Besides, NAL has provided a $270 \mathrm{kv}$ generator set to backup power supply at the hospital. Moreover, NAL has built bungalows for doctors and nurses at the Ntotroso hospital. This has resolved accommodation issues for the clinical staff. The above health related CSR by NAL is captured in their annual sustainability report as follows:

More than 1100 community members near Ahafo and ... ....... nearly 200 people near our Merian operation in Suriname attended health fairs and clinics (Newmont Sustainability Report, 2019 p. 13) (Newmont, 2019b Sustainability Report).

"Health centers in Ghana ... .... and Suriname received equipment and supplies, which were donated by medical companies and other organizations, valued at nearly \$1.9 million”. (Newmont Sustainability Report, 2019 p.13) (Newmont, 2019b Sustainability Report).

Furthermore, four different containers of medical equipment have been supplied to the health facilities in the district. Training workshops have been organized for nurses and midwives in the district health facilities to help neonatal cases. These have had significant impact in terms of reduction in both infant and maternal mortality rates in the communities. This is because accessibility to quality healthcare facilities and services has been enhanced significantly.

In reality, healthcare programs have benefited the community directly and indirectly, especially when calculated against the demographic makeup of the research area. It has also resolved morbidity issues. This outcome demonstrates that activities taken by NAL with regard to its CSR has enhanced the quality and effectiveness of health care in the community. The community acknowledged this initiative as one of the respondents reiterated that:

“... the mining company has put up a male and female blocks and this is very good for the community. Not long ago, my daughter had to be admitted in the female block because her medical condition had gotten bad" (Community resident 3).

Another respondent was also of the opinion that:

"... our operating theatre had not been well established before, but the mining company has built new operating theatre services that contribute greatly to the health of the community people". (Community 2).

Similarly, other respondents indicated that:

\section{"... hmmm, this time around doctors and nurses live much closer to the hospital and they respond quickly to cases any time because of the accommodation fa- cilities that was built by Newmont"[...] "... also we have even given electricity generator as a backup power supply in the government health facility be- cause the electricity situation in the country is very bad". (Community representative 1).}

The quotations above indicate that, people and the neighborhoods' are not only aware of initiatives being undertaken in the community by NAL, but also support this effort as it is directly profiting them and thus lessening some health burdens they were troubled with. Investment in the healthcare system as a CSR program is buttressed by Asongu, Uduji, and Okolo-Obasi (2019), who believed that sustained participation by companies in CSR leads to sustainable growth thus, enhancing community residents' quality of life. But further than this, a big issue is, if NAL's healthcare initiatives correspond in size or alleviate the environmental effects on the community, particularly as mining companies are known for causing serious harms to the environment and expanding the pattern of health related illnesses (Ofori \& Ofori, 2019).

\section{Education}

As part of their CSR practices pertaining to education, NAL has put up classrooms for ten towns and villages which include: Ntotroso, Kenyasi No. 1, Kenyasi No. 2, Gyedu, Wamahinso, Susuanso, Terchire, Yamfo, Afirisipakrom, and Adrobaa. Additionally, financial aid packages have been 
granted to more than 1000 students in the district's secondary and tertiary institutions. Moreover, NAL has made donations of teaching and learning resources such as books, bags, furniture and sport wears to the schools. NAL again sponsors academic and multimedia programs called "Edutainment", where the top students are awarded prizes. Such investment efforts in the educational system have contributed a long way to increasing the student enrolment and retention in schools. It has also eased pressure from some guardians of the payment of school fees. Moreover, interactions with the District Assembly, as a major stakeholder, revealed that NAL's investment in the field of education facilitates the efforts of the District Assembly, since this is mostly in line with the Assembly's educational policy objectives. This point confirms Amponsah-Tawiah and Dartey-Baah (2016), understanding that companies' programs as in CSR must move hand in hand with government's development priorities. Incidentally, interactions with relevant stakeholders in the community indicated that they were conscious of the significance of NAL's educational infrastructures and programs as part of its CSR. This was confirmed by a respondent:

"Newmont Ahafo Limited has sponsored education and culture activities such as inter-school play (edutainment), as well as funding for many poor but talented students in all levels of education". (Manager 3).

“... Truthfully speaking, Newmont Ahafo Limited has assisted the educational system by refurbishing and constructing classroom blocks for all communities impacted. The mining firm provided furniture, sport wears school bags, and uniforms for the school children”. (Community resident 1).

Another respondent from NAL was also of the opinion that:

“... with regards to education, we help our native communities by putting up classroom blocks for the educational institutions, renovating some of the old school blocks that are deteriorated. Again we have constructed a dormitory accommodation for the Kenyasi No. 2 Nursing School whiles construction of Bungalow for the Principal of the vocational school is currently on-going" (Manager 1).

An employee added that:

"We arranged inter-school contest for the District schools. Also, we have awarded students scholarships and again provided schools with learning resources, to mention but a few". (Employee 3).
NAL has invested in the school system and scholarship programs in the study communities. As it can be seen as a way to build young people's capacity and skill sets, it inevitably addresses a significant developmental concern. As shown in the survey community profile, a significant majority of the population fell within the 0-19 age category. Hence, primary education needs to be given the serious consideration in the communities. Those who are currently in Senior High School are 6.8\%, whereas those in tertiary education are less than $1 \%(0.7 \%)$ since 2010. The delivery of this school infrastructure and financial aid thus meets the educational needs of the community, in addition to being a CSR project. This finding is in line with Ismail, Alias, and Rasdi (2015), who discovered that one of the primary objectives of CSR academic programs in Malaysia was to enhance the literacy level for adults, which as of 2008 was $92.1 \%$ for all those aged 15 years and older.

\section{Water and sanitation}

Another form of CSR undertaken by NAL is water and sanitation program in which the company has developed new water systems like boreholes, pipelines and water storage systems for the researched communities. The firm has improved the current water system and designed a water house for members of the water board to consult and address project issues. NAL has built a mechanized landfill site for garbage. This was done in an attempt to improve sanitation in the affected communities. It has also built toilet facilities for families and latrines for general use. It was confirmed during an interview with one of the chiefs and an EPA official that NAL has established a water source for the community. One of the chiefs therefore remarked:

“... In fact, NAL has taken a huge burden off our shoulders. My people in the community suffered serious water shortage when we were in our old habitats; however, relocating to our new homes has solved the problem". (Community representative 2).

"NAL has constructed a large water reservoir which provides water to the whole community in addition to the boreholes they have developed". (Regulator 3).

The above quotations show the positive results of supplying the inhabitants with water. In addition, NAL's provision of several communities with stand pipes has decreased the distances residents will have to stretch to get access to portable water, particularly to nearby streams. This finding is in agreement with (Prno \& Slocombe, 2014) where she observed that a percentage of the mining communities had access to drinking water. 
The discussion shows that the community recognizes major projects that NAL is undertaking to improve economic and social life of the local people. Such acknowledgment establishes credibility that is a significant component of ensuring that NAL activities are maintained in the study communities. The legitimacy theory according to Fernando and Lawrence (2014) holds that legitimacy affects not only people's actions towards organizations, but also how people perceive them. Observers therefore recognize the legitimacy of the organization not only as more dignified, but also as more purposeful, easy to predict and credible. The theory further suggests that, in any socially formed set of expectations, principles and convictions, people consider that an organization's acts are good, moral or necessary.

The legitimacy theory seeks to explain why companies should engage in activities that do not provide direct financial reward. Thus, a key objective is when a firm can maintain its legitimacy, often working to gain legitimacy or to ensure that they retain their legitimacy. In light of this, the study was keen to know how NAL has retained its legitimacy given by society and also whether NAL engages in sustainable CSR activities for some reasons that do not provide the firm with direct financial benefit in line with societal expectations. Nevertheless, the debate so far indicates that NAL has acquired some reputation through its CSR activities, which is crucial to improving legitimacy, as Meyer, Li, and Schotter (2020) assume.

\section{Quality of life}

NAL initiatives which have increased the quality of life of both the workers and the local community is in the form of safety and protection, production of human capital, improvement of livelihoods and rural development. The firm has established police station and transit police accommodation at Ntotroso. It has also purchased police patrol cars to improve community security and safety. NAL has organized vocational and apprenticeship training programs for youth in the communities through its human resource development program, building their capacity to work in mining companies and other institutions. Moreover, NAL has organized entrepreneurship coaching through the OLIVES for traders and businessminded individuals in the study communities where proper costing, contracting and capability development were treated. OLIVES offers business lessons to businessmen and traders so that their enterprises can grow. Owing to the training programs, such vendors have been able to supply NAL with goods and services at a profit. NAL's CSR programs often aim to improve the living standards of local residents within the catchment areas of the company. The Livelihood Enhancement Services Organisation has implemented livelihood improvement programs for NAL. Some of these programs are the
"Mmobrowa" (Needy) program, the Livelihoods Enhancement and Community Development Program (LECDeP), the Agriculture Improvement and Land Access Program (AILAP) and the Agriculture Intervention Program (AIP). Membership of the "Mmobrowa" program is represented mainly by "Yamfo inhabitants". The purpose for this was to revitalize local residents who might have lost their livelihood opportunities through the activities of NAL and who have sadly also been expelled from their communities. Thus, the "Mmobrowa" initiative focused on the vulnerable people in the resettlement area who come under one of the following categories: widows, blind, elderly or people with physical disabilities. Foodstuffs and an amount of money per month are amongst the support they received. In its aim to enhance its people's living standards even further, NAL has initiated yet another program called LECDeP to support the "Mmobrowa" project. The "Mmobrowa" category encompasses individuals who were good enough to engage in commerce or agriculture. The LECDeP program was intended primarily for people who had been signed up in "Mmobrowa" initiative for at least 6 months and who were also involved in livelihood activities. They lost their capital to small businesses as a result of their resettlement, but LECDeP provided support to small businesses under the guidance and support of a committee made up of the Budget Manager, the Ghana Health Service, delegates of the chief, social welfare, legislators of farmers in the community and OLIVES. In this context some participants indicated that:

“... we processed oil palms, corn mail, processed gari, buying and selling foodstuffs, sold smoked fish and kept cold fish. We discussed with OLIVES if we can get some sort of package, we can initiate the processing again so that I can shift out of the "mmobrowa" community when we get the funds. In no time, my application was approved [...]" (Community resident 4).

“... I could indeed take my first stock if I ever get a deep freezer, GHc500 cash ... I mentioned to OLIVES. Once I submitted the proposal, OLIVES' business analyst went to purchase the freezer and offered me funds to buy the first order. Amusingly, some of us who last year pursued this LECDeP program were able to produce 5 sacks of maize. The revenue we got was put back in the enterprise". (Community resident 1).

It can be understood from the discourse that NAL has made and continues to make substantial investment through some form of economic empowerment, especially for those less endowed in the community. Although it may be expected that NAL's operations 
adversely impact the environment, it would not preclude the truth that NAL fulfills its moral obligations to the communities. In view of this, it can be mentioned that the CSR programs of NAL correspond with the definition of Osei-Kojo and Andrews (2020), which involves social and economic investment in the lives of less endowed people in society while adapting their necessities to the strategic objectives, particularly those related to society. Moreover, NAL as a multinational company based in Ghana, also supports (Ofori \& Debrah, 2014) claims that internationally-related Ghanaian companies appear to have a better understanding of CSR than local companies and that they live up to their ethical obligations. Nevertheless, it is acknowledged that this study is not a comparative review of the corporate responsibility activities between local and international corporations.

\section{Agriculture}

The Agriculture Improvement and Land Access Program (AILAP) is a mediation program with the purpose of replacing two acres of land for all affected local farmers with funding for agricultural inputs such as citrus, oil palm and cocoa seedlings, plantain suckers, corn seeds and an amount of cash to support the farm for 2 years. The study revealed that some skills training was also provided to cocoa farmers to empower beneficiaries with modern methods. OLIVES organized this training package. Additionally, persons who were interested in doing backyard garden were supported in the form of net, fence, seeds and were motivated to plant more vegetables for domestic use.

Another component of agricultural activity is animal breeding, such as rabbits, goats, sheep and poultry. Farmers who showed interest received the necessary training to equip them to properly domesticate animals. Several homes had goat cage, piggery, while others had small goats or fowls with no structure, OLIVES supported them with the structure and added goats or birds.

\section{Environment}

Although operations of the mining company have damaged the forest, yet, NAL has undertaken tremendous afforestation activity by replanting three trees to restore every single tree that is cut. Again, there have been tree planting activities in the neighborhoods and around primary schools to provide clean air for persons residing in the communities. The available data showed that NAL is determined to work to restore the forest area that has been destroyed by mining activities. The firm has established a new nursery through its environmental department, which is run by representatives of the local community. This program has had a great impact since its introduction and it has presented over 2000 new young trees and this pattern is likely to continue for the foreseeable future (Osei-Kojo \& Andrews, 2020). Thus, the effect on the environment is sustainable. This tree planting activity could also be seen as an effort helping to eradicate the imbalances created by the activities of NAL to the natural ecological system. Although this may be in line with the question of environmental sustainability, it has also provided jobs for some of the young people.

From the above discussions, it is obvious that NAL has shown a great deal of engagement in terms of CSR. This has significantly contributed to the economic growth of the neighborhood, while also enhancing the quality of life of the workers and their households, as well as the local community and the society in general. In addition, the nature and form of the initiatives have benefited the study communities enormously by enhancing both the quality of life and economic expansion.

Furthermore, a noteworthy issue is that while some of these initiatives may be perceived by NAL as CSR initiatives, they are key developmental programs essential to improve the area's economic growth. Consequently, CSR initiatives such as the "Mmobrowa" scheme, the LECDeP, the AILAP, the Agricultural Intervention Program and the Business Intervention Program are regarded by NAL as initiatives because they are crucial to the economic and social development of the area.

\section{Newmont's mode of stakeholder engagement in CSR practices}

The second objective of the research was to ascertain; to what extent stakeholders contribute to the sustainability of CSR outcomes. The only means by which stakeholders could contribute to sustainable CSR practice is through effective stakeholders' engagement practice. Stakeholders' engagement is crucial to a successful project execution since it contributes to participation and satisfaction of stakeholders (Oppong, Chan, \& Dansoh, 2017). Stakeholder engagement demands that the firm and its stakeholders have some sort of interaction or relationship. This research, however, focused on secondary stakeholders as opposed to primary stakeholders. Secondary stakeholders include those entities or groups who the company relies on and typically do not partake in dealings with the focal agency including consumers, vendors, states, associations, communities and the public at large (Latif \& Sajjad, 2018).

The study showed that the secondary stakeholders with whom NAL has been associated with were representatives from local authorities whose neighborhoods host mining activities, NADeF, SDC, EPA, OLIVES, Ghana Education Service, Assembly members, community delegates, and affected farmers. From the data collected, NAL contacts the different stakeholders 
according to their involvement schedule in the year. In addition, stakeholders are approached by invitation as the first step especially in the form of letters issued by the administration to the various categories of stakeholders. Generally, what the firm would do is to visit traditional leaders at durbars before projects begin and over there the rulers are told of the project's scope. These meetings are important in that they allow contributions to the design and preparation, execution and oversight of these projects. It also provides the basis for the people to understand that the project is for them and not something forced on them by the mining companies.

\section{Involvement of stakeholders in decision making}

NAL perceives engagement with stakeholders as very critical and has established engagement schedules. There are specific communication plans for the diverging groups of stakeholders (Morsing \& Schultz, 2006). Per reactions from the respondents, stakeholders participate in decisions regarding development programs in the communities concerned. NAL plans and prioritize with stakeholders initiatives which will support community members. To ensure that NAL does not initiate white elephant projects, stakeholders are actively involved in every step all the way from the planning level to the post-execution level of project development for effective project execution and sustainability.

The involvement of stakeholders has helped to maintain a friendly and cooperative relationship with the management of NAL, resulting in project sustainability and its results. For example through participation and a sense of ownership of the projects by the people, there are no conflicts between NAL and the people. This situation is so different from other issues occurring in mining communities where there is constant conflict between local residents and mining companies due to misgivings (Marfo, 2019). In addition, through these partnerships and involvement of stakeholders in development-related decisions, units and bodies such as NADeF and SDCs have been established to increase the efforts of NAL by offering both the technical and supervisory role of CSR programs and the results (Morsing and Schultz (2006). The quotation below from one executive of NAL illustrates this point.

“... We like to see them owning the projects. This has been noticed that when stakeholders are engaged right from the outset of the programs, they tend to own it and when they own it they will sustain it. Besides, owning the project, they facilitate the planning of various programs within the communities, they take actions, bring forward plans for acceptance by the Newmont management. As stakeholders reside in the community, they know what kind of ventures that are helpful to them". (Manager 3).

We are involved in decisions regarding community developments. We usually have quarterly meeting with management of NADeF on community development matters where we discuss progress for the last quarter and the way forward (Community representative 2).

Additionally, these units/bodies established as a result of the various stakeholder involvements have been crucial to guaranteeing project success by regularly inspecting project sites and tracking project progress and deviations. Two of the community respondents said:

“... While I represent my community at the engagement session, I am connected with the SDCs created by engagement with NAL. I agree that projects can be sustained because the SDCs are responsible for managing and reviewing the projects". (Community representative 1).

"We have site meetings of projects periodically to track the progress of projects. We also previously asked Newmont Ahafo Ltd to join on-site sessions, but now we have the NADeF representing NAL and the SDCs serving representatives from various communities". (Community Representative 2).

This finding seeks to reiterate a position strongly held by (Asante Boadi et al., 2019) that understanding the principles underlining the engagement of stakeholders is a crucial step towards establishing a strong involvement in programs. The engagement process, for example in construction projects, helps project advocates and stakeholders interact effectively (Freeman \& Dmytriyev, 2017). The scholars again explained that the Stakeholder Engagement Program should not be ignored as it identifies stakeholder concerns and integrates them into a project scheme to accomplish teamwork integrated project development. This study thus seems to depart from most mining communities in developing African nations where mining communities are in persistent conflict with mining firms due to inadequate participation mechanisms of stakeholders (Hilson, 2007).

\section{Consultation/dialogue}

The study showed that interaction was also a realistic development tool where stakeholders' concerns were taken into account in decision-making and their contributions manifested in the outcome. Through interaction, the company knows better the perspective and concerns of the community. Chen, Marfo, and $\mathrm{Hu}$ (2016), argued 
that constructive engagement of stakeholders in the process has to be shared through sincere communication between stakeholders and organization management. Whenever the firm plans to introduce any type of CSR program, the very first action was to consult with the community, because the community members will ultimately be the program's end users. This was reported in Newmont Annual report that:

Before any resettlement activities begin, we work with local stakeholders and international experts to develop a resettlement action plan (RAP) to address the impacts of physical displacement, and/or a livelihood action plan (LAP) to address the economic impacts or land use. Sites regularly monitor RAPS and LAPs and are required to conduct annual audits by qualified external experts to ensure activities are meeting the commitments made and the needs of affected persons (Newmont Sustainability Report, 2019.p 53) (Newmont, 2019b Sustainability Report).

One society member confirmed that:

"... Yeah, we are contacted and the consultation comes in the form of an introductory letter to the king makers and the different stakeholders concerned. Newmont does not start programs without first talking to our traditional leaders. I can confirm that Newmont engages our leader in conferences and durbars where they discuss initiatives to be undertaken". (Community member 2).

The company will first introduce the initiative before the stakeholders during the consultation/interaction sessions for the participants to deliberate and make a substantial contribution. During meetings the stakeholders help to make decisions, plan, execute and review projects. At meetings, stakeholders are encouraged to share their viewpoints and the firm values their views. Interactions with stakeholders confirmed that different stakeholder groups are invited to all discussions and consultation sessions and their input is always integrated. The classifications of stakeholders defined at meetings include local authorities (district assembly), NAL, NADeF, SDCs, Unit committee members, representatives of different groups including youth and traditional leaders. More also, those very representation encourages balance at group discussion. Such consultation indirectly affected the sustainability of CSR projects and their results. A good example is the current arrangement on the percentage of income of ounce of gold to be provided by NAL to the treasury of NADeF which was defined by the communities and NAL.

\section{Collaboration}

NAL through the establishment (NADeF) has an arrangement with the Social Responsibility Forum (SRF) and the SDC to jointly plan initiatives with regards to the thematic areas and implement the projects. The Forum is an effective tool which draws together the community and other major stakeholders, notably national and district authorities, NGOs, women and youth, to create a 60 -member SRF. The aim of this forum is to cooperate with NADeF and highlight the key community development initiatives which need to be adopted as NAL's CSR programs, thus ensuring creative approaches to the challenges of limited resources. The quotation below from a NAL official illustrates this point.

“... We have a joint project consisting of NAL, the District Assembly as well as the communities and the cooperation is phenomenal. Every community has a seven-member committee known as Committee for Sustainable Development (SDC)”. (Employee2).

"They collaborate on behalf of the community with the foundation as well as SRF to manage development programs. And so it's not just consultation, it's planning with them and carrying out projects with them ... it is called collaborative and participatory planning, that is we do it together..." (Manager 3).

Also, another officer from NADeF said that:

“... Initiatives are planned with the assistance of SDCs, based on the capital available...It is a pragmatic participatory planning which is driven by the community members themselves. The foundation does not plan projects for the communities, but we offer advice and support based on the outcome of the need assessment”. (Employee 2).

One NADeF official also stated that:

“... as stated above, we are mindful of sustainability, before we start any program, we consider needs assessment, we seek to involve stakeholders, we factor in their input, We provide them with advice about how to handle responsibilities, because when Newmont eventually folds up those initiatives need to go on. So, from the very beginning we include stakeholders, we put District Assemblies, the SRF as well as some other partner agencies like NADeF on board and we collaborate with them to guarantee sustainability".(NADeF).

Stakeholders such as top management within SDCs play a critical role by closely monitoring projects and 
reporting any issue to the required departments. The members of the SDC were organized under NADeF and as aspect of the foundation deal, this select committee is a seven-member committee constituted in all of the four communities to represent traditional authorities, women, young people and the public at large. As part of the NADeF treaty, the SDCs were equipped for each community on how to carry out needs assessment and engineer projects NADeF should be financing on the basis of the results of the needs assessment. Incidentally, placing the key points against the stakeholder participation ladder of (Kazmi, Leca, \& Naccache, 2016) a similar situation arises. Scandelius and Cohen (2016), defines this as collaboration, and this level of engagement as when stakeholders begin to gain and maintain real control over their desires or demands. This is a relationship where the distribution of control between the power holders and the stakeholders is established right from the outset. This finding confirms a research by Boso et al. (2017), which showed that the local community is a very key stakeholder in small enterprise and project development activities.

It can be confirmed according to the above discussions that an organization needs to factor in relevant stakeholder engagement strategy to guarantee the sustainability of its CSR outcome. The findings are consistent with Abukari and Abdul-Hamid (2018), study, which stated that stakeholder involvement is among the nine major promoting and adversely affecting factors of CSR for enterprises in sub-Saharan Africa. Their findings again showed that a very high level of coordination between these stakeholders and corporate entities is therefore essential for businesses to obtain credibility and establish social and economic value. To facilitate or achieve effective execution of CSR, managers have to create relationships with their stakeholders through official and unofficial interaction and engagement activities (Andrews et al., 2019). This research further found that stakeholders of the contemporary corporate system surpass even the immediate business climate and include investors, local communities, government and the general public at large.

In addition, the numerous partnerships, meetings and collaborations that have been crucial in promoting the different CSR ventures and outcomes echo (Freeman \& Dmytriyev, 2017), opinion that underpinning stakeholder theory is the concern of stakeholder relationships that is essential to both the sustainability and the continued activity of the company. Again, the stakeholder theory argues that businesses can be seen as structures whose survival is based on their ability to meet a specific audience known as stakeholders who can be described by their rights, ownership or concerns in a business and its operations, past, present or future (Kujala \& Korhonen,
2017). In addition, the debate also dealt with the proposed idea, which stated that the degree of stakeholder participation affects the sustainability of CSR results. This is also shown by different bodies and departments formed as a result of the numerous consultations and engagement. Such bodies have been crucial to promoting and sustaining CSR initiatives and outcomes as mentioned in earlier parts of this section.

\section{Implications of findings}

The study's findings indeed provide important theoretical and practical implications as follows. Practical implications: The provision of hospitals/clinics implies that accessibility to quality healthcare facilities and services would be improved considerably. The institution of educational scholarships and classroom blocks means that the less endowed and needy children will get better education. Another important implication is that the existing CSR outcomes should be monitored and managed more closely by the different stakeholder groups to include a real and thorough evaluation of the viability of programs of mining companies. Again, mining companies should work with non-governmental organizations to assist community beneficiaries to generate ready markets for their products and services which in so doing will alleviate poverty. Moreover, mining firms should engage themselves in the choice of stakeholder representatives for concerned communities and educate the host communities about the significance of voluntary participation in program timetables and engagement meetings. These measures would enhance engagement of stakeholders, particularly at the local level, where project outcomes are experienced much more. The research results of Korppi et al. (2019), describe how organizational leadership and learning are involved as vital factors for sustainable CSR programs. Furthermore, it is imperative for national governments to compel mining companies to establish scholarship schemes for their host communities. Theoretical implications: The information on the relationship between CSR and stakeholders behavior permits companies to apply CSR strategies to assist them achieves greater stakeholder engagement and, therefore, increases the general performance of their companies.

\section{Conclusions}

The study was carried out with a total of 21 selected respondents from various stakeholder groups in the catchment areas of the company, management and other employees of the mining company. These respondents were ready and able to take part in the study and were also accessible at the time of the study. They were divided into three categories: Newmont management and other employees, local residents and representatives and District officials. Feedback was gathered from interviews, 
and observations using a semi-structured interview guide as the study's main tool. To incorporate management and stakeholders' perspectives on the effect of stakeholder participation on the sustainability of CSR results, two different interview guides were produced for management and stakeholders and their feedback were evaluated descriptively. Data obtained from the respondents were first transcribed, coded and examined by the use of thematic analysis and themes were identified indicating relationships and connections between concepts and key ideas in the phenomenon.

The study's results showed how NAL in Ghana has taken proactive steps to sustainably meet the socioeconomic needs of its impacted communities. The company linked discretionary CSR with stakeholder approach to achieving sustainable results, setting up partnerships with appropriate government and NGOs to implement CSR programs. The degree and extent of stakeholder participation processes have improved partnerships between the stakeholders and NAL.

The structure and shape of the CSR interventions were focused on both direct and indirect needs of people in the community. It can be summarized, therefore, that the CSR programs of NAL are self-sustaining as a result of its strategic goal to extend the life span of initiatives. CSR results have ultimately greatly impacted on the triple bottom line sustainable practices comprising economic, social and environment. We, thus, reach the conclusion that successful stakeholders' engagement in CSR initiatives of mining companies' has facilitated a cordial relationship free of disputes in the mining communities of NAL.

The findings show that stakeholders in the mining areas are involved in the CSR meetings and discussions organised by NAL. Moreover, we also draw the conclusion that the level of their contribution and participation has led to sustainable CSR results which will benefit generations unborn. Finally, the study found that the integration of stakeholder strategies into CSR resulted in excess demand from various stakeholders. This usually increases the company's role and responsibility and costs, resulting in poor voluntary involvement by stakeholders.

\section{Limitations of the study and future research}

It is inappropriate to make generalizations of the findings of this study. This apparent lack of generalizability stem from the fact that the study was conducted at Newmont Ahafo Ltd. located in Kenyasi in the Ahafo Region, hence, ignoring Newmont Akyem Ltd. in the Eastern Region, and other mining companies in Ghana such as Goldfields Tarkwa mine and AngloGold Obuasi mine. That notwithstanding, the findings may be broadly applicable to gold mining firms in Ghana but it cannot be generalized to other mineral extraction sectors in Ghana or those in other geographic areas and other African countries. Consequently, the results cannot be used as yardstick for other developing countries. It is therefore suggested that further studies involving a cross-industry contrast of stakeholder participation and the sustainability of CSR results in Ghana and other emerging countries could be conducted. This would give communities the opportunity to learn the different strategies that industries are pursuing to sustain their CSR activities in the area of community growth. Besides, it is notable that due to hectic schedules of some of the managers, initially; they were unwilling to take part in the interviews. However, this constraint was surmounted by going to them personally and appealing to them to answer the interview questions whiles reducing the interview times. Even in all instances, the interviews were recorded to avert any danger of eroding the data's quality. Moreover, in a qualitative study like ours, detailed interviews were used to collect data and measures (ie, moderation) were put in place to overcome the flaws related to subjectivity. It is also notable that though there were interview guides which were prepared in English, yet the interviews were conducted in our local dialect "Akan". The seeming problem of respondents misunderstanding resulting from such process was decreased because the researchers were native "Akan" speakers. Finally, the sustainability of CSR results and stakeholder participation could be conducted among various industries. In so doing, host communities will be acquainted with different strategies that these businesses are pursuing to sustain their CSR activities.

\section{Appendix I}

Interview guide for respondents

Stakeholder engagement and Corporate Social Responsibility (CSR) A case study of Newmont Ahafo Mines.

INTERVIEW GUIDE FOR NEWMONT MANAGE MENT/ STAFF NEWMONT AHAFO DEVELOPMENT FOUNDATION (NADeF)

The aim of the study is to determine the nature and form of CSR projects and the extent to which stakeholders are engaged in CSR. This exercise is only for academic purposes and any information provided will remain confidential and anonymous. Thank you for your participation in this exercise.

SECTION A: DEMOGRAPHIC CHARACTERISTICS

\begin{tabular}{llllll}
\hline Gender: & Male [ & Female [ & & & \\
2.Age: $\left(\begin{array}{lllll}\text { (a) } 20-29( & \text { (b) } 30-39 & \text { (c) } 40-49 & \text { (d) } 50-59 & \text { (e) } 60+ \\
\hline\end{array}\right.$
\end{tabular}

Highest educational level attained:

(a) JHS (b) SHS (c) Diploma (d) Undergraduate. 
(e) Postgraduate (f) No formal education (g) Professional Certificate.

SECTION B: THE NATURE AND FORMS OF CSR PROJECTS

1. What is the nature and form of Corporate Social Responsibility (CSR) projects undertaken by Newmont?

2. What kind of CSR projects are undertaken by Newmont in the affected communities?

a) How has the organisation categorized the various forms of CSR projects undertaken in the affected communities?

b) Are some of the CSR projects temporary and what is the estimated life span? Are some of the CSR projects permanent and what is the estimated lifespan?

3. What is the nature and form of Corporate Social Responsibility (CSR) projects and their sustainability level derived by Newmont?

a) How does your organisation sustain or ensure continuity of the various forms of CSR projects undertaken in the affected communities?

b) How does your organisation determine the sustainability level of the various forms of CSR projects in the affected communities?

c) Who is responsible for the sustainability of CSR projects in your organisation? What role do the stakeholders play in ensuring the sustainability of CSR projects in the communities?

4. To what extent do stakeholders contribute to the sustainability of Corporate Social Responsibility (CSR) projects?

a) Why must stakeholders in the affected communities be involved in CSR projects?

b) How do you think stakeholders' participation in decisions on CSR ensures sustainability of projects?

c) How would management describe the rate of stakeholders' engagement in achieving sustainable CSR projects?

\section{Appendix II}

Stakeholder engagement and Corporate Social Responsibility practices of the Ghanaian mining sector. A case study of Newmont Ahafo Mines

\section{Interview guide for stakeholders}

The aim of the study is to determine the nature and form of CSR projects and the means stakeholders are engaged in the process. This exercise is only for academic purposes and any information provided will remain confidential and anonymous. Thank you for your participation in this exercise.

\section{Section A: Demographic characteristics}

1. Gender: Male [] Female [].
2. Age: (a) 20-29
(b) $30-39$
(c) $40-49$
(d) 50-59 (e)

$60+$.

3. Highest educational level attained:

(b) JHS (b) SHS (c) Diploma (d) Undergraduate.

(e) Postgraduate (e) No formal education (f) Professional Certificate

Section B: The nature and forms of CSR projects

1. What is the nature and form of CSR projects undertaken by Newmont?

a) What type of CSR projects does Newmont undertake in your community? Mention them.

b) Do the people in the community benefit from these projects? How?

c) What do you think will be the reasons why Newmont supports community development?

d) Do you receive any donation in these forms? Example:

i. Medicine ii. School uniform iii. Farm products iv. Fund v. scholarship Any other;

e) What is the form of CSR projects?

Example

Categorization Form

Infrastructural development

Health

Education

Community development

\section{To what extent do stakeholders contribute to the CSR practices?}

3. As stakeholders in the community are you consulted before CSR projects are initiated?

4. Do you contribute at meetings before any CSR project is undertaken?

5. Do you think your contributions are reflected in the CSR outcomes?

6. Do you make decision over a project by negotiation?

7. Are you consulted after a change has been made on decisions on CSR projects? 
8. Describe your engagement in decision making on CSR projects by ticking YES or NO.

\begin{tabular}{l}
\hline Engagement Processes \\
\hline Management calls for meetings to solicit our views on \\
projects \\
Agreement letter is sent to us to sign \\
A representative is chosen to speak on our behalf \\
We are given the opportunity to contribute at meetings \\
We decide on projects that will benefit the community \\
We receive feedback from management
\end{tabular}

\section{Appendix III}

\section{Coding of interviews results}

Coding I: The nature and form of CSR projects at Newmont Ahafo.

\section{First-order codes \\ Newmont is helping us a lot. They constructed a clinic for us with which has helped in reducing the struggles we use to go through 5 years ago. We had to travel with patience several miles to access health facilities at Bechem [a town which is about $20 \mathrm{~km}$ from this town] (Community resident 6) \\ "... our operating theatre had not been well established before, but the mining company has built new operating theatre services that contribute greatly to the health of the community people". (Community 2) \\ My son had admission to University of Ghana 6 years ago, but I had no hope of getting money to send him to school. We apply for scholarship from Newmont Foundation and lucky for us, his application was accepted. Even though we support him, the scholarship package take care of all the tuition fees Community Resident 5)}

... with regards to education, we help our native communities by putting up classroom blocks for the educational institutions, renovating some of the old school blocks that are deteriorated. Again, we have constructed a dormitory

accommodation for the Kenyasi No. 2 Nursing School whiles construction of Bungalow for the Principal of the vocational school is currently on-going (Manager 1).

My people used to walk like 5 miles Water and before getting access to potable Sanitation
Coding of interviews results (Continued)

First-order codes Second-order Aggregated categories theme

water. Newmont has drilled about four boreholes for my community and that has been a big relief. In fact, it has even reduced the infections that we were getting from drinking contaminated water (Traditional Ruler)

"NAL has constructed a large water reservoir which provides water to the whole community in addition to the boreholes they have developed". (Regulator 3).

Newmont provides community members with jobs and the salaries are very good. In fact,

unemployment in our community is very low compared other areas in this country. Once you are a youth from nearby communities, it is easy to get at least menial jobs from Newmont (Community Resident 4)

I couldn't get a job at Newmont. But I have been enrolled at the Bamboo Bicycle Factory which was established by NADeF in Gyedu [a host community of Newmont Ahafo] to offer training to the youth in to manufacture bamboo bicycles.

Newmont Ahafo Foundation has put in place several programs to improve the economic lives of the people. Some of them are the Livelihoods Enhancement and Community Development Program (LECDeP), the Agriculture Improvement and Land Access Program (AILAP) and the Agriculture Intervention Program (AIP)(NADeF)

We have several pollution preventive measures in place to avoid spillage of chemicals into the environment. We also have a list of environmentally friendly chemical that we are permitted to use as a way of avoiding the usage of harmful chemicals (Manager 2)

The mining firm [Newmont] has consistently being reclaiming the lands which has been mined and disturbed. Even though there are several acres to be rehabilitated, I think they are not doing that bad (NGO, Environmentalist)

"foundation does not plan projects for the communities, but we offer advice and support based on the outcome of the need assessment". (Employee 2)

Coding II: Mode of stakeholder engagement at Newmont Ahafo
Economic empowerment

Agriculture

Environment 


\begin{tabular}{|c|c|c|}
\hline First-order codes & $\begin{array}{l}\text { Second-order } \\
\text { categories }\end{array}$ & Aggregated theme \\
\hline $\begin{array}{l}\ldots \text { I can confirm that } \\
\text { through community } \\
\text { representatives to NADeF, } \\
\text { Newmont engages our }\end{array}$ & $\begin{array}{l}\text { Involvement of } \\
\text { Stakeholders in } \\
\text { decision making }\end{array}$ & $\begin{array}{l}\text { Newmont's mode of } \\
\text { stakeholder } \\
\text { engagement in CSR } \\
\text { practices }\end{array}$ \\
\hline
\end{tabular}

eaders in conferences

and durbars where they

discuss initiatives to be

undertaken. (Community

member 2)

Before we established the Bamboo Bike Factory, we consulted the community involved on the sustainable nature of the project and the financial benefits that comes with it. If they had rejected our proposal, that would have been the end of story because the funds for the project was their quota from NADeF (Manager 2)

Most of the time they ask us what the community needs before a project takes off. They also invite the community leaders for meetings to seek their opinions on the needs of the communities.

(Community

representative)

Yeah, we are contacted and the consultation comes in the form of an introductory letter to the king makers and the different stakeholders concerned. I know that mostly, Newmont does not start programs without first talking to our traditional leaders (Community member 2)

We have collaborated with host communities to establish a bamboo bicycle factory. This factory was established with funds of the two beneficiary communities [Ntotoroso and Gyedu] which was their share of contributions from Newmont to NADeF (NADeF)

... Initiatives are planned with the assistance of SDCs [Sustainable

Development

Committees], based on the capital available ...t is a pragmatic participatory planning which is driven
Consultation/

Dialogue

Collaboration

Coding of interviews results (Continued)

\begin{tabular}{|c|c|c|}
\hline First-order codes & $\begin{array}{l}\text { Second-order } \\
\text { categories }\end{array}$ & Aggregated theme \\
\hline $\begin{array}{l}\text { by the community } \\
\text { members themselves. } \\
\text { (Employee } 2 \text { ) }\end{array}$ & & \\
\hline
\end{tabular}

\section{Abbreviations}

AlLAP: Agricultural Improvement and Land Access System; CSR: Corporate Social Responsibility; EPA: Environmental Protection Agency; JHS: Junior High School; LECDeP: Livelihoods Enhancement and Community Development Program; NADeF: Newmont Ahafo Development Foundation; NAL: Newmont Ahafo Ltd; NAM: Newmont Ahafo Mines; NGGL: Newmont Ghana Gold Limited; NGOs: Non-Governmental Organizations; NMC: Newmont Mining Corporation; OLIVES: Organization for Livelihood Enhancement Services; SDC: Sustainable Development Committee; SHS: Senior High School

\section{Acknowledgements}

We would like to thank all the interviewees for accepting to partake in the research. Words cannot express how grateful we are to the managers of Newmont Ahafo mines, employees and all the stakeholders for sparing a little bit of their time. We would also like to thank the Cologne Business School (CBS) for funding the article-processing charge.

\section{Authors' contributions}

All the authors read, contributed, and approved the final manuscript.

\section{Funding}

Apart from the article-processing charge (APC) which was borne by Cologne Business School (CBS), Germany, this research received no funding.

\section{Availability of data and materials}

Due to ethical considerations, confidentiality and privacy of respondents were assured and therefore, data provided by the respondents would be kept confidential and cannot be shared.

\section{Competing interests}

All authors declare not having any competing interests.

\section{Author details}

${ }^{1}$ Department of Marketing, Faculty of Business and Management Studies, Sunyani Technical University, Sunyani, Bono Region, Ghana. ${ }^{2}$ Department of Entrepreneurship and Business Sciences, School of Management Sciences and Law, University of Energy and Natural Resources, Sunyani, Bono Region, Ghana. ${ }^{3}$ Office of the Registrar, Academic Affairs and Admissions Unit, Sunyani Technical University, Sunyani, Bono Region, Ghana. ${ }^{4}$ Department of Accountancy, Faculty of Business and Management Studies, Sunyani Technical University, Sunyani, Bono Region, Ghana.

Received: 24 September 2020 Accepted: 27 November 2020 Published online: 02 January 2021

\section{References}

Ablo, A. D. (2020). Enterprise development? Local content, corporate social responsibility and disjunctive linkages in Ghana's oil and gas industry. The Extractive Industries and Society, 7(2), 321-327.

Abugre, J. B. (2014). Managerial role in organizational CSR: Empirical lessons from Ghana. Corporate Governance, 14(1), 104-119

Abugre, J. B., \& Anlesinya, A. (2019). Corporate social responsibility and business value of multinational companies: Lessons from a sub-Saharan African environment. Journal of African Business, 20(4), 435-454.

Abugre, J. B., \& Anlesinya, A. (2020). Corporate social responsibility strategy and economic business value of multinational companies in emerging economies: The mediating role of corporate reputation. Business Strategy \& Development, 3(1), 4-15.

Abukari, A. J., \& Abdul-Hamid, I. K. (2018). Corporate social responsibility reporting in the telecommunications sector in Ghana. International Journal of Corporate Social Responsibility, 3(1), 2. 
Adnan, S. M., Hay, D., \& van Staden, C. J. (2018). The influence of culture and corporate governance on corporate social responsibility disclosure: A cross country analysis. Journal of Cleaner Production, 198, 820-832.

Adongo, R., Kim, S. S., \& Elliot, S. (2019). "Give and take": A social exchange perspective on festival stakeholder relations. Annals of Tourism Research, 75, 42-57.

Adusei, C. (2017). Accounting on social and environmental reporting in the extractive industry of Ghana: Perspectives of mining staffs. American Journal Economics Finance and Management, 3(3), 20-32.

Aggarwal, P., \& Singh, A. K. (2019). CSR and sustainability reporting practices in India: An in-depth content analysis of top-listed companies. Social Responsibility Journal, 15(8), 1033-1053.

Agudelo, M. A. L., Jóhannsdóttir, L., \& Davídsdóttir, B. (2019). A literature review of the history and evolution of corporate social responsibility. International Journal of Corporate Social Responsibility, 4(1), 1.

Amoako, G. K. (2017). Relationship between corporate social responsibility (CSR) and corporate governance (CG): The case of some selected companies in Ghana. In Responsible corporate governance, (pp. 151-174). Switzerland: Springer.

Amponsah-Tawiah, K., \& Dartey-Baah, K. (2016). Corporate social responsibility in Ghana: A sectoral analysis. In Corporate social responsibility in sub-Saharan Africa, (pp. 189-216). Switzerland: Springer.

Andrews, N., Andrews, N., \& Yurova (2019). Gold mining and the discourses of corporate social responsibility in Ghana. Switzerland: Springer.

Ansong, A. (2017). Corporate social responsibility and firm performance of Ghanaian SMEs: The role of stakeholder engagement. Cogent Business \& Management, 4(1), 1333704.

Asante Boadi, E., He, Z., Bosompem, J., Say, J., \& Boadi, E. K. (2019). Let the talk count: Attributes of stakeholder engagement, trust, perceive environmental protection and CSR. SAGE Open, 9(1), 2158244019825920.

Asongu, S. A., Uduji, J. I., \& Okolo-Obasi, E. N. (2019). Transfer pricing and corporate social responsibility: Arguments, views and agenda. Minera Economics, 32(3), 353-363.

Bice, S., Brueckner, M., \& Pforr, C. (2017). Putting social license to operate on the map: A social, actuarial and political risk and licensing model (SAP model). Resources Policy, 53, 46-55.

Boadi, E. A., He, Z., Darko, D. F., \& Abrokwah, E. (2018). Unlocking from community stakeholders, corporate social responsibility (CSR) projects for effective company-community relationship. Labor History, 59(6), 746-762.

Boso, R. K., Afrane, S. K., \& Inkoom, D. K. (2017). Motivations for providing CSRmediated initiatives in mining communities of Ghana: A multiple-case study. International Journal of Corporate Social Responsibility, 2(1), 7.

Brooks, C., \& Oikonomou, I. J. T. B. A. R. (2018). The effects of environmental, social and governance disclosures and performance on firm value: A review of the literature in accounting and finance. The British Accounting Review 50(1), 1-15.

Brueckner, M., \& Eabrasu, M. (2018). Pinning down the social license to operate (SLO): The problem of normative complexity. Resources Policy, 59, 217-226.

Brunson, J. C., \& Laubenbacher, R. C. (2018). Applications of network analysis to routinely collected health care data: A systematic review. Journal of the American Medical Informatics Association, 25(2), 210-221.

Campopiano, G., \& De Massis, A. (2015). Corporate social responsibility reporting: A content analysis in family and non-family firms. Journal of Business Ethics, 129(3), 511-534.

Carroll, A. B., \& Brown, J. A. (2018). Corporate social responsibility: A review of current concepts, research, and issues. In Corporate social responsibility. UK: Emerald Publishing Limited.

Chedrawi, C., Osta, A., \& Osta, S. (2020). CSR in the Lebanese banking sector: A neo-institutional approach to stakeholders' legitimacy. Journal of Asia Business Studies, 14(2), 143-157.

Chen, L. Z., Marfo, E. O., \& Hu, X. H. (2016). Corporate social responsibility behavior: Impact on Firm's financial performance in an information technology driven society Paper presented at the International Journal of Engineering Research in Africa.

Coffie, W., Aboagye-Otchere, F., \& Musah, A. (2018). Corporate social responsibility disclosures (CSRD), corporate governance and the degree of multinational activities. Journal of Accounting in Emerging Economies, 8(1), 106-123.

Corvellec, H., \& Stål, H. I. J. S. (2019). Qualification as corporate activism: How Swedish apparel retailers attach circular fashion qualities to take-back systems. Scandinavian Journal of Management, 35(3), 101046.
Creswell, J. W. (2014). Research design: Qualitative, quantitative and mixed methods approaches, (4th ed., ). Thousand Oaks: Sage.

Damoah, O. B. O., Peprah, A. A., \& Cobla, G. M. (2019). The state of corporate social responsibility research in Ghana: A synthesis of literature. Business Strategy \& Development, 2(4), 303-314.

Del Baldo, M., \& Aureli, S. (2019). Anticipating and assessing corporate social responsibility within ISO 26000 implementation: The experience of Camst cooperative (Italy). In ISO 26000-a standardized view on corporate social responsibility, (pp. 115-136). Switzerland: Springer.

Deng, X. (2012). Understanding consumer's responses to enterprise's ethical behaviors: An investigation in China. Journal of Business Ethics, 107(2), 159181.

Erdiaw-Kwasie, M. O., Alam, K., \& Shahiduzzaman, M. (2017). Towards understanding stakeholder salience transition and relational approach to 'better'corporate social responsibility: A case for a proposed model in practice. Journal of Business Ethics, 144(1), 85-101.

Fernández-Llamazares, Á., Garteizgogeascoa, M., Basu, N., Brondizio, E. S., Cabeza, M., Martínez-Alier, J., ... Reyes-García, V. (2020). A state-of-the-art review of indigenous peoples and environmental pollution. Integrated Environmental Assessment and Management, 16(3), 324-341.

Fernando, S., \& Lawrence, S. (2014). A theoretical framework for CSR practices: Integrating legitimacy theory, stakeholder theory and institutional theory. Journal of Theoretical Accounting Research, 10(1), 149-178.

Foss, N. J., \& Klein, P. G. (2018). Stakeholders and corporate social responsibility: An ownership perspective. In Sustainability, stakeholder governance, and corporate social responsibility. UK: Emerald Publishing Limited.

Franklin, A. L. (2020). Facilitating stakeholder participation. In Stakeholder engagement, (pp. 97-120). Cham: Springer.

Freeman, R. E., \& Dmytriyev, S. (2017). Corporate social responsibility and stakeholder theory: Learning from each other. Symphonya Emerging Issues in Management, 1, 7-15.

Ghana - Total Labor force, TLF (2019) https://www.indexmundi.com/facts/ghana/ indicator/SL.TLF.TOTL.IN. Accessed 17 Sep 2019

Goby, V. P., \& Nickerson, C. (2016). Conceptualization of CSR among Muslim consumers in Dubai: Evolving from philanthropy to ethical and economic orientations. Journal of Business Ethics, 136(1), 167-179.

Gold, S., Muthuri, J. N., \& Reiner, G. (2018). Collective action for tackling "wicked" social problems: A system dynamics model for corporate community involvement. Journal of Cleaner Production, 179, 662-673.

Halme, M., Rintamäki, J., Knudsen, J. S., Lankoski, L., \& Kuisma, M. (2020). When is there a sustainability case for CSR? Pathways to environmental and social performance improvements. Business \& Society, 59(6), 1181-1227.

Harjoto, M., \& Laksmana, I. (2018). The impact of corporate social responsibility on risk taking and firm value. Journal of Business Ethics, 151(2), 353-373.

Hasan, I., Kobeissi, N., Liu, L., \& Wang, H. (2018). Corporate social responsibility and firm financial performance: The mediating role of productivity. Journal of Business Ethics, 149(3), 671-688.

Hermelline, M. K. R., \& Beddewela, E. (2019). The politics of corporate social responsibility in the mining industry in Burkina Faso. Africa Journal of Management, 5(4), 358-381.

Hilson, A., Hilson, G., \& Dauda, S. (2019). Corporate social responsibility at African mines: Linking the past to the present. Journal of Environmental Management, 241, 340-352.

Hilson, G. (2007). Championing the rhetoric?'Corporate social Responsibility'in Ghana's mining sector. Greener Management International, 53, 43-56.

Idowu, S. O., Capaldi, N., Fifka, M. S., Zu, L., \& Schmidpeter, R. (2015). Dictionary of corporate social responsibility: CSR, sustainability, ethics and governance. Switzerland: Springer

Iglesias, O., Markovic, S., Bagherzadeh, M., \& Singh, J. J. (2020). Co-creation: A key link between corporate social responsibility, customer trust, and customer loyalty. Journal of Business Ethics, 163(1), 151-166.

Ismail, M., Alias, S. N., \& Rasdi, R. M. (2015). Community as stakeholder of the corporate social responsibility programme in Malaysia: Outcomes in community development. Social Responsibility Journal, 11(1), 109-130.

Kapoor, K. K., Tamilmani, K., Rana, N. P., Patil, P., Dwivedi, Y. K., \& Nerur, S. (2018) Advances in social media research: Past, present and future. Information Systems Frontiers, 20(3), 531-558.

Karlöf, E., Seime, T., Dias, N., Lengquist, M., Witasp, A., Almqvist, H., .. Maegdefessel, L. (2019). Correlation of computed tomography with carotid plaque transcriptomes associates calcification with lesion-stabilization. Atherosclerosis, 288, 175-185. 
Kazmi, B. A., Leca, B., \& Naccache, P. (2016). Is corporate social responsibility a new spirit of capitalism? Organization, 23(5), 742-762.

Khan, A., Muttakin, M. B., \& Siddiqui, J. (2013). Corporate governance and corporate social responsibility disclosures: Evidence from an emerging economy. Journal of Business Ethics, 114(2), 207-223.

Korppi, M., Mecklin, M., \& Heikkilä, P. (2019). Review shows substantial variations in the use of medication for infant bronchiolitis between and within countries. Acta Paediatrica, 108(6), 1016-1022.

Kowalczyk, R., \& Kucharska, W. (2020). Corporate social responsibility practices incomes and outcomes: Stakeholders' pressure, culture, employee commitment, corporate reputation, and brand performance. A polishGerman cross-country study. Corporate Social Responsibility and Environmental Management, 27(2), 595-615.

Kucharska, W., \& Kowalczyk, R. (2019). How to achieve sustainability?-Employee's point of view on company's culture and CSR practice. Corporate Social Responsibility and Environmental Management, 26(2), 453-467.

Kujala, J., \& Korhonen, A. (2017). Value-creating stakeholder relationships in the context of CSR. In Stakeholder engagement: Clinical research cases, (pp. 63-85). Switzerland: Springer.

Lamb, S., Jennings, J., Calain, P. J. T. E. I., \& Society (2017). The evolving role of CSR in international development: Evidence from Canadian extractive companies' involvement in community health initiatives in low-income countries. The Extractive Industries and Society, 4(3), 614-621.

Laosirihongthong, T., Samaranayake, P., Nagalingam, S. V., \& Adebanjo, D. (2020) Prioritization of sustainable supply chain practices with triple bottom line and organizational theories: Industry and academic perspectives. Production Planning and Control, 31(14), 1207-1221.

Latif, K. F., \& Sajjad, A. (2018). Measuring corporate social responsibility: A critical review of survey instruments. Corporate Social Responsibility and Environmental Management, 25(6), 1174-1197.

Lee, L., \& Chan, K. (2017). Practices of CSR in China and Hong Kong. In Handbook of integrated CSR communication, (pp. 317-341). Switzerland: Springer.

Lenssen, J. M., \& Yuthas, Y. (1997). Corporate social performance, stakeholder orientation, and organizational moral development. Journal of Business Ethics, 16(12-13), 1213-1226.

Lenz, I., Wetzel, H. A., \& Hammerschmidt, M. (2017). Can doing good lead to doing poorly? Firm value implications of CSR in the face of CSI. Journal of the Academy of Marketing Science, 45(5), 677-697.

Lewa, P. M. (2020). CSR case studies of selected blue Chip companies in Kenya. In Social entrepreneurship and corporate social responsibility, (pp. 373-388). Switzerland: Springer.

Looser, S., \& Mohr, S. (2020). Creative education \& political systems their common effect on sustainable business attitudes. The International Journal of Management Education, 18(3), 100383.

Luu, T. T. (2019). CSR and customer value co-creation behavior: The moderation mechanisms of servant leadership and relationship marketing orientation. Journal of Business Ethics, 155(2), 379-398.

Marfo, E. O. (2019). Heralds of corporate irresponsible behavior: Using partial Least Square approach of structural equation modeling Paper presented at the International Journal of Engineering Research in Africa.

Marfo, E. O., Amoako, K. O., Antwi, H. A., Ghansah, B., \& Baba, M. G. (2017). Corporate social responsibility: Institutional behavior differences in extractive industry Paper presented at the International Journal of Engineering Research in Africa.

Martinez-Conesa, I., Soto-Acosta, P., \& Palacios-Manzano, M. (2017). Corporate social responsibility and its effect on innovation and firm performance: An empirical research in SMEs. Journal of Cleaner Production, 142, 2374-2383.

Martínez-Ferrero, J., Garcia-Sanchez, I. M., \& Cuadrado-Ballesteros, B. (2015). Effect of financial reporting quality on sustainability information disclosure. Corporate Social Responsibility and Environmental Management, 22(1), 45-64.

Martínez-Ferrero, J., Rodríguez-Ariza, L., \& García-Sánchez, I.-M. (2016). Corporate social responsibility as an entrenchment strategy, with a focus on the implications of family ownership. Journal of Cleaner Production, 135, 760-770.

Mehahad, M. S., \& Bounar, A. (2020). Phosphate mining, corporate social responsibility and community development in the Gantour Basin, Morocco. The Extractive Industries and Society, 7(1), 170-180.

Mensah, H. K., Agyapong, A., \& Oteng-Abayie, E. F. (2017). Making corporate social responsibility work: Do rural and community banks (RCBs) in Ghana care at all? The Qualitative Report, 22(11), 2904-2925.

Meyer, K. E., Li, C., \& Schotter, A. P. (2020). Managing the MNE subsidiary: Advancing a multi-level and dynamic research agenda. Journal of International Business Studies, 51(4), 538-579.
Mohammed, W. F., Xiao, A., \& Hilton, E. (2019). A critical analysis of corporate social responsibility in Ghana's telecommunications industry. Communicatio, 45(3), 4-22.

Morsing, M., \& Schultz, M. (2006). Corporate social responsibility communication: Stakeholder information, response and involvement strategies. Business Ethics: A European review, 15(4), 323-338.

Nave, A., \& Ferreira, J. (2019). Corporate social responsibility strategies: Past research and future challenges. Corporate Social Responsibility and Environmental Management, 26(4), 885-901.

Newmont 2019a Annual Report https://www.annualreports.com/Company/ newmont-mining. Accessed 17 Aug 2019.

Newmont 2019b Sustainability Report https://s24.q4cdn.com/382246808/files/ doc_downloads/2019/sustainability/Newmont-2019-sustainability-report.pdf. Accessed 15 Aug 2019.

Nichols, P. M., \& Dowden, P. E. (2019). Maximizing stakeholder trust as a tool for controlling corruption. Crime, Law and Social Change, 71(2), 171-195.

O'Dwyer, B., \& Unerman, J. (2016). Fostering rigour in accounting for social sustainability. Accounting, Organizations and Society, 49, 32-40.

Ofori, D. F., \& Debrah, Y. (2014). Corporate social responsibility in sub-Saharan Africa: Hindering and supporting factors. African Journal of Economic and Management Studies, 5(1), 93-113.

Ofori, J. J. Y., \& Ofori, D. R. (2019). Earning a social license to operate: Perspectives of mining communities in Ghana. The Extractive Industries and Society, 6(2), 531-541.

Oppong, G. D., Chan, A. P., \& Dansoh, A. (2017). A review of stakeholder management performance attributes in construction projects. International Journal of Project Management, 35(6), 1037-1051.

Osei-Kojo, A., \& Andrews, N. (2020). A developmental paradox? The "dark forces" against corporate social responsibility in Ghana's extractive industry. Environment, Development and Sustainability, 22(2), 1051-1071.

Panda, S. S., \& Barik, A. (2014). How to make stakeholder engagement meaningful. Growth Journal of the Management Training Institute, 42(1), 7-14.

Park, B. I., Chidlow, A., \& Choi, J. (2014). Corporate social responsibility: Stakeholders influence on MNEs' activities. International Business Review, 23(5), 966-980.

Patnaik, S., Temouri, Y., Tuffour, J., Tarba, S., \& Singh, S. K. (2018). Corporate social responsibility and multinational enterprise identity: Insights from a mining company's attempt to localise in Ghana. Social Identities, 24(5), 604-623.

Pirson, M., Martin, K., \& Parmar, B. (2017). Formation of stakeholder trust in business and the role of personal values. Journal of Business Ethics, 145(1), 1-20.

Prno, J., \& Slocombe, D. S. (2014). A systems-based conceptual framework for assessing the determinants of a social license to operate in the mining industry. Environmental Management, 53(3), 672-689.

Ranängen, H. (2017). Stakeholder management theory meets CSR practice in Swedish mining. Mineral Economics, 30(1), 15-29.

Rendtorff, J. D., Adams, G. B., Balfour, D. L., Althammer, J., Andersen, K., Andersen, N. $\AA$., ... Crowther, D. (2018). Governmentality and the politics of CSR. In Cosmopolitan Business Ethics: Towards a Global Ethos of Management (Vol. 17), (pp. 1-6). London: Random House Armonk.

Ronnegard, D. (2009). CSR in the Gulf region: Corporate philanthropy likely to remain key for now https://knowledge.insead.edu/csr/csr-in-the-gulfregion-2233. Accessed 3 Nov 2020.

Sajjad, A., \& Eweje, G. (2014). Corporate social responsibility in Pakistan: Current trends and future directions', corporate social responsibility and sustainability: Emerging trends in developing economies (critical studies on corporate responsibility, governance and sustainability, volume 8). In Emerging trends in developing economies, (pp. 163-187). Bingley: Emerald Publishing.

Sarpong, S. (2017). Corporate social responsibility in Ghana: Issues and concerns. In Corporate social responsibility in times of crisis, (pp. 191-205). Switzerland: Springer.

Saunders, S. (2012). Corporate social responsibility: A helping hand for a better Belize. International Journal of Business and Social Science, 3(9), 174-177.

Scandelius, C., \& Cohen, G. (2016). Achieving collaboration with diverse stakeholders-The role of strategic ambiguity in CSR communication. Journal of Business Research, 69(9), 3487-3499.

Shiu, Y. M., \& Yang, S. L. (2017). Does engagement in corporate social responsibility provide strategic insurance-like effects? Strategic Management Journal, 38(2), 455-470.

Shnayder, L., van Rijnsoever, F. J., \& Hekkert, M. P. (2016). Motivations for corporate social responsibility in a packaged food industry: An institutional and stakeholder management perspective. Journal of Cleaner Production, 122, 212-227. 
Sodhi, M. S., \& Tang, C. S. (2018). Corporate social sustainability in supply chains: A thematic analysis of the literature. International Journal of Production Research, 56(1-2), 882-901.

Unerman, J., \& Zappettini, F. (2014). Incorporating materiality considerations into analyses of absence from sustainability reporting. Social and Environmental Accountability Journal, 34(3), 172-186.

White, C. L., \& Alkandari, K. (2019). The influence of culture and infrastructure on CSR and country image: The case of Kuwait. Public Relations Review, 45(3), 101783.

White, C. L., \& Fitzpatrick, K. R. (2018). Corporate perspectives on the role of global public relations in public diplomacy. The Public Relations Journal, 11(4), 313-331.

World Population Review (2019). Ghana population (demographics, maps, graphs), 2019 Accessed 17 Sep 2019, https://worldpopulationreview.com/countries/ ghana-population/.

Yang, J., Ma, J., \& Doty, D. H. J. F. B. R. (2020). Family involvement, governmental connections, and IPO underpricing of SMEs in China, (p. 0894486520905180).

Yang, Y., \& Stohl, C. (2020). The (in) congruence of measures of corporate social responsibility performance and stakeholder measures of corporate social responsibility reputation. Corporate Social Responsibility and Environmental Management, 27(2), 969-981.

Zhang, Q., Oo, B. L., \& Lim, B. T. H. (2019). Drivers, motivations, and barriers to the implementation of corporate social responsibility practices by construction enterprises: A review. Journal of Cleaner Production, 210, 563-584.

\section{Publisher's Note}

Springer Nature remains neutral with regard to jurisdictional claims in published maps and institutional affiliations.

\section{Submit your manuscript to a SpringerOpen ${ }^{\circ}$ journal and benefit from:}

- Convenient online submission

- Rigorous peer review

- Open access: articles freely available online

- High visibility within the field

- Retaining the copyright to your article

Submit your next manuscript at $\boldsymbol{\nabla}$ springeropen.com 